When analyzing the labor market, it is possible to observe that there are also gender disparities, both in occupations and in relation to wages. Inequalities in the labor market by gender can negatively impact people's living conditions and economic efficiency, contributing to increasing poverty and social inequalities.

Wage inequalities between men and women in Brazil can be verified through the analysis of average wages. According to RAIS (BRASIL, 2016a), the average remuneration measured in reais in 2014 for men in Brazil was 2.651,52 reais, while for women it was 2.184,65 reais. Women received lower average wages and these differences need to be explained in some way.

A discussion about wage differentials, the main approach of this research, needs to take into account the possible determinants. Fiuza-Moura (2015) points out that several recent theories try to explain the wage differences in the labor market. Therefore, starting from this context, the research problem is: what theories can be used to try to explain wage inequalities and what public policies could be devised to minimize this problem?

Thereby, the general objective of this paper is to present the theories that can be used to try to explain wage inequalities and to address public policies and actions that could be elaborated to minimize this problem, paying special attention to the wage inequalities of origin discriminatory against women.

It is important to identify what elucidates wage differentials by gender, so that policies and actions can be created and implemented to combat them. In addition, reducing wage inequalities can be important for reducing poverty, improving the wellbeing of the population and equality between people.

Furthermore, the Federal Constitution of Brazil of 1988 (BRASIL, 1988), when it refers of the fundamental rights and duties of individuals in article 5, shows that men and women should be treated equally, both in relation to rights and obligations. When alluding to social rights, in article 6 , it is pointed out that both the difference in salary, the exercise of the job and admission criteria between persons according to sex, age, color or marital status are prohibited. These two legal provisions make clear the need for equal treatment for men and women.

This research has a qualitative character and will be developed based on the bibliographical references.

This article is organized as follows, in addition to this introduction: section 2 presents the gender inequalities in the labor market, both wages and employment; section 3 shows the methodology to be used; section 4 presents the results and discussions; And finally, in section 5, the final considerations of the research.

\section{Gender inequalities in the labor market}

This section aims to address some aspects that contribute to the existence of wage inequalities and differences in the labor market by gender. The main focus of the analysis is the woman in the market, since the existence of wage differences and occupation between men and women is visible.

Inequalities in the labor market between men and women are found all over the world. However, these differences, which are transformed into inequalities, attract the attention of the current society, which is increasingly seeking equality, justice and social and individual well-being (CHAHAD, 2009). 
According to Abramo (2004), gender inequalities and discrimination are two elements that mark society and labor relations. In this way, inequalities and discrimination are closely intertwined, one contributing to the existence of the other. Abramo (2004) still demonstrates that the forms of inequalities contribute to social exclusion, which in turn contributes to the increase of poverty. Therefore, inequalities and discrimination act as a barrier, which prevent discriminated groups from overcoming poverty and social exclusion.

To analyze the insertion of women in the labor market, we need to analyze a series of factors. The first of these are the constraints imposed by productive responsibilities. The woman is also given a very great weight in the care of the children, the house, and the elders. All these tasks take time, which hampers their insertion in the labor market (ABRAMO, 2004).

Absences and interruptions due to maternity and childcare can make the insertion of women more restricted in the labor market. The more discontinuous work of women, because of the main fact of needing to move away to exercise motherhood, makes men often preferable to women to employment (YANNOULAS, 2002). The lack of day-care centers in most Brazilian cities only exacerbates this situation (BRUSCHINI; LOMBARDI, 2001).

In addition to productive responsibilities, there are also cultural factors, which often discourage women's work. The idea that the woman has a care function and the man of family provider is still very present in society. What aggravates this situation is that, often, when the woman works, her work is considered only complementary to that of her husband (ABRAMO, 2004).

Despite all these problems that hinder the insertion of women, some factors were fundamental for increasing female participation in the labor market. Advances in medicine have contributed greatly to this increase. In 1960, they began to have access to effective contraceptive methods, which made it possible to limit the number of children, allowing them to plan family size and entry into the labor market. From that period, the participation of women in all levels of education has increased (BELTRÃO; ALVES, 2009).

Bruschini and Lombardi (2007) and Bruschini, Ricoldi and Mercado (2008) highlight the role of schooling. Women with higher levels of education have been occupying jobs traditionally considered masculine, such as medicine, law, architecture, engineering, and are considered a factor of progress achieved by women.

The increase of women in more and more qualified occupations is a result of the intense cultural transformation that has taken place since the late 1960s and the expansion of public and private universities in Brazil (BRUSCHINI, RICOLDI AND MARKET, 2008).

However, Melo (2005, p.17) shows that "despite the decrease in gender inequality that occurred in the 1990s, the obstacles to access to leadership positions have not been overcome, as well as gender differences in earnings". Sabino and Lima (2015) in their study emphasized that the insertion of women into politics is also fraught with exclusion and prejudice. Even in 2012 a woman occupying the highest position of power in Brazil, the number of women participating in the political scenario is very reduced compared to the women's population representation. 
Yannoulas (2002) reports that many advances have already been made regarding the insertion of women in the world of work. However, the legislation and policies implemented are still not enough or are done precariously, so that some forms of discrimination still remain.

For Leone and Baltar (2006), the increase in women's participation in economic activities has not yet been able to reverse the enormous inequality in the labor market, which is reflected in lower wages, higher unemployment and greater informal employment. The important improvement in rights and opportunities for women still needs to be developed in order to be equal in relation to men, and in this process, higher education plays a fundamental role.

The promotion of equality in the world of work, according to Yannoulas (2002), needs to be fomented by public policies, given the inefficiency of the markets to regulate in relation to these inequalities and discriminations.

The woman, as already mentioned, suffers serious problems for her insertion and participation in the labor market: cultural factors, maternity, traditional occupations, among others. All these factors contribute to the existence of wage differentials between men and women.

\section{Methodology}

This research has a qualitative character characterized as descriptive and will be formulated from bibliographical references.

\section{Results and discussions}

This section will address the theories that seek to explain the wage inequalities described in the literature.

Ramos and Vieira (2001) point out four factors that seek to explain the wage differentials of labor market participants: the first theory he calls compensatory differentials, which are the additional gains for jobs that require greater risks, unsanitary, among others; The second theory refers to differences in the productive attributes of workers, that is, differences in human capital, such as education, experience, among others; The third shows the wage differences arising from segmentation in the market, where workers are equally productive but receive different remunerations because of the way they are inserted, often based on regional, sectoral differences; And the latter refers to wage discrimination, where the market remunerates participants based on non-productive attributes such as color, sex, etc.

In this way, the following will be presented, in detail, theories that seek to explain wage inequalities. These theories serve to explain wage inequalities in general, among genders, races, color, etc., but are used here to focus on wage inequalities between genders.

\section{Theory of compensatory differentials}

According to Fernandes (2002), the wage is not the only variable to be taken into account when firms and workers decide their supply and demand for labor. According to him, workers may be interested in the conditions and work environment, such as risk of accidents, insalubrity, safety at work, among others. If the work offers good 
conditions, the worker will be willing to receive a lower salary for those characteristics that he considers favorable. For firms, offering these environments has a cost, so they would also be willing to pay lower wages for that. The result would be lower wages for jobs considered more work-friendly. According to Fernandes (2002) this is the basis of the theory of compensatory differentials for non-pecuniary aspects.

Arbache (2000: 144) makes some considerations:

"The theory of wage compensation is based on the hypothesis that workplace conditions affect the performance of the worker. Jobs that offer safety or health hazards or even if they are unpleasant have to be properly "compensated" to attract job applicants. The principle is simple: the worker

Fernandes (2002) points out that the theory of compensatory differences is widely used to explain wage differentials between jobs. For example, it may be useful to explain wage differentials between regions, such as regions where crime is larger, more polluted, and with greater congestion; To explain the differences in wages in relation to length of stay in employment, differentiated shifts, flexible working hours and unemployment risk; And also to explain the wage differentials between men and women. In the case of women, if they want, for example, jobs that allow the reconciliation of childcare and domestic work with work in the market, they could accept a lower salary for those characteristics considered favorable.

Thus, at least part of the wage gap in the labor market could be explained by the theory of compensatory differentials. However, it is not the only one used to try to explain wage differentials

\section{The human capital theory}

According to Lima (1980), until the end of the 1950s, human capital issues were not very important, mainly because countries were more concerned with achieving full employment and smoothing economic cycles. Income distribution was seen only as direct income transfers. In the 1960s, however, the theory of human capital gained importance as countries began to worry about achieving economic growth.

According to Schultz (1961), human capital refers to a stock of skills and knowledge internalized in the person, capable of generating higher income and product, because it makes it possible to improve their productivity. Becker (1962) reports that for the theory of human capital, as a person's level of education increases, so does their income, because it is embedded within the neoclassical assumptions that assume that the factors are remunerated according to their productivity. For Schultz (1961), when a person uses part of his leisure time to improve his skills and knowledge, he is investing in human capital. In addition, he points out that more educated and educated people tend to receive higher wages because they are more productive than others who do not invest in education and training.

For Schultz (1961), the theory of human capital is actually a theory of investment or accumulation of capital in the individual, and this accumulated capital refers to education, training, professional experience, health care, among others. 
Becker (1962) reports that different investments in human capital may be useful in trying to explain the differences in remuneration between people. In the same sense, Cirino (2008) points out that the theory of human capital also applies to explain the differences in pay between men and women, trying to determine why women's wages are often lower than men's. Becker (1962) states that women may have less incentive to invest in human capital, as they have historically had lesser shares in the labor market. Cirino (2008) concludes that greater discontinuities due to childcare and domestic activity may also influence women's decision to invest in human capital. This can make them have lower work experiences, and thus lower productivity and lower wages. However, Cirino (2008) also makes considerations in the sense that women are increasingly being inserted into the labor market and wage inequalities are decreasing.

Although it is not the only one trying to explain the causes of wage differentials, the theory of human capital searches for variables such as schooling and worker experience, a determining factor for wage inequalities in the labor market, so it will be one of the theories used to the explanation of wage differences. Variables such as employment time and schooling will be used to try to capture the effects of human capital on workers' wages.

\section{Theory of segmentation}

Lima (1980) shows that in the late 1960s and early 1970s, much criticism began to emerge regarding the theory of human capital, even though no new theory to emerge in opposition. However, in the 1980s, began to gain form a new theory seeking to complement that of human capital, and explain the duality in labor markets, the theory of segmentation.

For Fernandes (2002) segmentation in the labor market refers to the separate or distinct markets, or to a set of models and theories that deal with the functioning of the labor market. Satel (2011, p.20) comments that "segmentation theory is related to the concentration of workers in a given market or occupation".

Several factors have been used as a form of segmentation, such as: geographic regions, sectors, industrial branches, demographic characteristics, syndicalizations, market regulation, among others (ARBACHE, NEGRI, 2002; FERNANDES, 2002).

Fernandes (2002) reports that wage differentials may exist in the different segments of the market, occurring, therefore, due to the mobility costs or nonpecuniary characteristics of the jobs of the different segments. For Lima (1980), when a person is allocated in a certain segment in the labor market, his salary will depend on the internal rules of that segment with respect to the wage standard imposed and not of the cognitive abilities, nor of the productivity of the worker, as predicted by Human capital theory.

Arbache and Negri (2002) report that, in recent decades, segmentation theory has been widely used to explain the dispersion and structure of wages in the labor market. It has been widely used as an alternative to neoclassical ideas, that is, neoclassicists emphasize the role of human capital as an explanation of wage inequalities. Segmentation theorists criticize this idea and also point to segmentation as the cause of wage inequalities. Fernandes (2002) points out that this segmentation liter- 
ature presents heterogeneous and broad ideas, and the main point of convergence among the authors is the positioning of all as to the criticism of neoclassical theory.

Therefore, the theory segmentation, by giving a fundamental role to the labor market, tries to explain the causes of wage differentials due to the different segments that the worker is inserted, which can be economic sectors, geographic regions, among others. In this sense, this research will not be limited to explaining the wage differences through the human capital theory, thereby, the theory of segmentation will also be one of the theories used to explain the wage differences. Variables such as establishment type and economic sectors will be used to try to capture the effects of segmentation on workers' wages.

\section{Theory of discrimination}

Rocha and Pero (2007: 124) point out that, for the theory of discrimination, an individual is discriminated against "if the contractor takes into account in choosing employment and wages not only objective aspects such as their productivity, but also subjective aspects, such as race or gender". Fernandes (2002: 42) comments that in situations of discrimination "equally productive people are evaluated differently by the market based on the group to which they belong".

The main consequences of discrimination, particularly in relation to women, are in discredited and poorly paid professions and occupations, impediments to job access, difficulties in career advancement, sexual harassment, among others (YANNOULAS, 2002).

Discrimination found in the labor market in relation to women or blacks can still be classified exclusively in four types, according to Loureiro (2003): wage discrimination, employment, occupation and access to human capital. Wage discrimination means that women or blacks receive lower wages for work equal to those of men and whites. Employment discrimination occurs when women and blacks receive fewer job opportunities than men and whites. Discrimination in occupation occurs when women and blacks are prevented from occupying certain jobs even though they have the same productive capacities. Finally, discrimination in access to human capital occurs when discriminated groups, such as women and blacks, are more restricted to increasing their qualifications and improving their knowledge, as a result of unequal opportunities in the labor market, that is, because they are in certain occupations less specialized, are restricted from obtaining greater knowledge and improvement in employment.

In conclusion, the theory of discrimination seeks to explain wage differentials, assigning a determining role to the individual and subjective characteristics of workers, such as sex, age, color, religion, among others.

Therefore, the wage differences can be explained by theories: compensatory differentials, human capital, segmentation and discrimination. The theory of compensatory differentials explains the extra gains for jobs that require greater risks and insalubrity. The theory of human capital seeks to explain the wage differences between men and women due to differences in education that these workers may present. The segmentation theory proposes to explain the wage differences due to the different segments of the market that men and women may be inserted. And the theory of discrimination will serve as a basis for explaining the wage differences not 
explained by the theory of human capital nor by segmentation attributed to the subjective characteristics of the workers.

Having presented the theories that serve as the basis for the explanation of the wage differences between men and women, one starts with a characterization of the actions and public policies aimed at minimizing gender inequalities, not only wage inequalities, but all kinds of differences that may exist between men and women.

\section{Characteristics of the actions and public policies concerned on the minimization of inequali- ties between men and women}

Chahad (2009) reports that the earliest international legislation aimed at vulnerable groups, such as women, emerged in the mid-nineteenth century, although they focused on protecting the role of women in society rather than on gender equality. These laws were designed to protect maternity and to prohibit women's work in some sectors considered unfit for women.

According to Bandeira (2005), the United Nations Charter of 1945 and the Universal Declaration of Human Rights of 1948 were the first documents of international protection of human rights that explicitly presented the idea that men and women should have Equal treatment in society.

According to Ferreira (2004), several paths have been crossed and obstacles have been overcome so that the governments of the western countries begin to reformulate the laws and change the legislation in order to prohibit discrimination against women. According to her, the first legal discrimination opposed was the prohibition of voting for women, then the differences in pay and then the inequalities of access and treatment in occupations should be tackled. Increased circulation of information, goods, services and people has contributed to globalizing and exposing inequalities and inequities in the distribution of income globally against specific groups.

Bandeira (2005, p. 52) describes some international events that marked the search for the consolidation of women's rights:

The Fourth World Conference on Women (Beinjing / 1995) also constituted another important milestone for the consolidation of legal mechanisms in favor of women. In addition to these, there are other important ones worth remembering: the World Conference on Human Rights (Vienna / 1993) which reaffirmed the human rights of women and girls as inalienable, integral, universal and indivisible. The Fourth World Conference on Population and Development (Cairo / 1994), inserting the discussion on sexual and reproductive rights. The Social Development Summit (Copenhagen / 1995), on the grounds that women are the most affected by the effects of poverty, unemployment, environmental degradation, violence and war, and that social and economic development can not be achieved without Inclusion of women. And finally, the World Conference against Racism, Racial Discrimination, Xenophobia and Related Forms of Intolerance (Durban / 2001), which drew attention to Afro-descendant and indigenous women and young people, doubly affected by sexual prejudice and racial prejudice. 
According to Ferreira (2004), after the Beijing Conference, approximately 70\% of countries began to develop plans to promote equality between men and women, highlighting the role of international actions in this regard. However, the lack of resources was the justification given by some countries for neglect of equality promotion actions. Silveira (2004) also points out the difficulties that the poorest countries faced in formulating gender policies, since resources were scarcer and there were many social demands besides women's demands.

In Brazil, the creation of public policies for vulnerable groups took a long time to start, since the government's concern was with macroeconomic policies to stabilize inflation and reduce external debt (CHAHAD, 2009). The feminist movement in Brazil, since the 1980s, has been demanding the creation of public policies focused on women. Increasing female participation in the labor market, in education, in the public sphere and in various segments of society contributes to strengthening these demands (GODINHO, 2004).

The Federal Constitution of 1988 attempted to ensure the protection of women by bringing laws that sought to eliminate discrimination and inequality to the female gender in the labor market (YANNOULAS, 2002). Beltrão and Alves (2009) pointed out that the Brazilian Constitution of 1988 became one of the most advanced in the world, with regard to the pursuit of gender equality, emphasizing that it required the holding of a public tender to fill vacancies in the public service, which favored the participation of women in several areas that were previously male.

Yannoulas (2002) points out that, in the Brazilian Constitution of 1988, the protection of the women's labor market was guaranteed, and any differential treatment with respect to salary, functions and admission criteria according to sex, age, color, among other attributes. However, Chahad (2009) points out that, even with the Constitution defending rights of equality between men and women, it was not until the 1990s that the first actions aimed at this end were started. The Public Employment System of this decade was the first step towards the creation of work and income programs and actions in Brazil. Bandeira (2005) points out that at the end of the second government of Fernando Henrique Cardoso, from 1999 to 2002, the Secretariat of State for Women's Rights (2002) was created, which was linked to the Ministry of Justice. The main actions of this secretariat were the fight against violence against women, the participation of women in the political scenario of the country and their insertion in the labor market.

In 2003, the creation of the Special Secretariat for Policies for Women (SEPM) was another step forward in relation to the creation of public policies. According to Chahad (2009), this secretariat promoted two policies aimed at women: the ProGender Equity Program and the Incentive to Women's Economic Autonomy in the World of Work and also developed actions, encouraging the generation of income and employment for women.

Since the creation of the Special Secretariat for Policies for Women, some actions have been designed and promoted by it, such as: in July 2004, the 1st National Conference on Policies for Women (1st CNPM), where the I PNPM; In August 2007, the 2nd National Conference on Policies for Women (2nd CNPM), which systematized a set of proposals and demands to the Brazilian State preparing the II PNPM; And the 
3rd National Conference on Policies for Women (3rd CNPM) held in December 2011, resulting in the PNPM 2013-2015 (BRASIL, 2013).

The National Policy Plan for Women (PNPM) aimed at strengthening the National Policy for Women approved from 2004 and reinforced in 2007 and 2011 by the respective conferences. In addition, it proposed promoting: women's autonomy; to seek effective equality between women and men; respect for diversity and combating all forms of discrimination; active participation of women in all phases of public policies, among other actions (BRASIL, 2013).

In October 2015, under the government of President Dilma Rousseff, the Ministry of Women, Racial Equality, Youth and Human Rights was created by MP 696, with the Secretary for Policies for the Promotion of Racial Equality (Seppir); Secretariat of Policies for Women (SPM); Secretariat of Human Rights (SDH) and National Youth Secretariat (SNJ). However, Provisional Measure No. 726, published in the Federal Official Gazette on May 12, 2016, established a new organizational structure for the Presidency of the Republic and the Ministries from the inauguration of the new President Michel Temer. This measure extinguished the Ministry of Women, Racial Equality, Youth and Human Rights, and established that SEPM should remain the Special Secretariat for Policies for Women, but it should be linked to the Ministry of Justice and Citizenship (BRASIL, 2016b).

At the end of 2015, the municipal and state stages of the 4th National Conference on Policies for Women (4th CNPM) were held, and in May 2016 the national stage of this Conference was held, with the theme of promoting more rights, participation and power for Women, with the main objective of strengthening the National Policy for Women (BRASIL, 2016c).

However, Chahad (2009) reports that legislations and public policies that seek gender equality in the labor market are not efficient in dealing with the size of the existing challenges. According to Ferreira (2004), although most structures are designed to promote equality between men and women, most of them are not being effective in their purpose, since there is a gap between formalized policies and policies implemented, in addition to lack of available resources and legislative regulation. Most of the time, policies are formalized by pressure from commitments made with various international bodies.

Ferreira (2004) points out that the pursuit of equality between men and women must be based on actions, in new strategic areas, that for it are: education, to generate equality and citizenship; combating pornography and trafficking in women; reproductive and sexual health; combating violence and the feminization of poverty, among others.

Several policies can be cited, among them: the creation of day care centers and schools that would directly contribute to increasing the participation of women in the labor market; provision of a second meal for the children at school; extension of school periods; greater vacancies in early childhood education, which would give the woman more free time to dedicate herself to improving her working life; policies to combat violence against women; attendance to cases of violence and opening of service stations for social demands; support network for women who use drugs, among others (GODINHO, 2004). 
Another important point is family actions, where women's roles should be reviewed as the sole responsibility for household chores and childcare, reducing the overload of responsibilities, allowing them some time for professionalization, culture and leisure. Other examples of policies aimed at women would be: self-determination policies that allow women to have full control of their bodies and freedom to exercise their sexuality; welfare policies aimed at guaranteeing sexual and reproductive rights: such as health and access to contraception; formulation of programs for social support such as the creation of collective laundries and popular restaurants; among others. All these and others already mentioned would contribute to the formation of female autonomy, citizenship and social restructuring (SILVEIRA, 2004).

The State plays a fundamental role in promoting equality, not only by regulating laws that prohibit differential treatment, but also as a driver of cultural change and in people's lives. The State has in its hands mechanisms that can create coordinations and secretariats to elaborate policies for women in order to reduce gender inequalities, as well as being able to dialogue with the social strata (SOARES, 2004).

Abramo (2004), regarding the effective creation of public policies, points out that it is necessary to understand the causes, the problems and the mapping of the most vulnerable groups, and then to create correct mechanisms of action. In addition, she said, the problems of women and blacks related to inequality and discrimination must be included in the public agenda. The creation of effective policies will only be possible by creating channels of dialogue with different social actors and by empowering managers, government, organizations and civil servants to develop concrete actions, as well as to qualify women's and black organizations to know Clear ideas for policy-making.

According to Arbache (2000), combating gender inequalities is important because they influence humanitarian and moral, economic and social issues. The problem of inequalities, especially of discrimination, has an influence on the decision to work and study, on the distribution of income and on productivity, so trying to minimize its effects should be a social objective.

The international actions presented, aimed at minimizing inequalities between men and women and increasing women's participation in the labor market, were the driving force for countries to start a greater concern with these issues. In Brazil, the actions and policies aimed at minimizing inequalities, although they appeared later, were also a reflection of this international movement, mainly by the feminist movements. All actions that have already been implemented or should be implemented are of fundamental importance in order to contribute to a greater insertion of women in the labor market and, consequently, to reduce inequalities between men and women. In addition to this, the role of the State is the driver of cultural and social changes for society, and is fundamental for the promotion of equality among people. Thus, studies and research are needed to highlight existing inequalities, as well as the dissemination of these studies to highlight the problem and encourage concrete actions to reduce social inequalities.

Once the actions and public policies aimed at minimizing inequalities between men and women have been characterized, a social evaluation is presented in the light of public policies focused on wage differentials due to discriminatory aspects. 


\section{Social analysis of discrimination}

Among the factors that can impact on wage inequalities is discrimination. The fact that there are wage differences, in most cases, in favor of men, is strongly linked to the discriminatory aspects against women. In order to minimize this problem, it can be said that policies and actions aimed at minimizing the problem of wage discrimination against women need to be developed and implemented, thus seeking to reduce wage inequalities. According to Barros and Mendonça (1996), the existence of discrimination in the labor market can generate some problems such as: reduction of efficiency of resource allocation; conflict generation in labor relations; decrease in the degree of cooperation between workers; declining productivity of the economy; inefficient composition of labor supply, and greater poverty.

Barros and Mendonça (1996) point out that anti-discrimination laws have been based, fundamentally, on four elements: equal opportunities; equal pay for equal work; similar payment for equivalent work; and reverse or positive discrimination. Thus, an action that could be implemented by the Government to reduce discrimination, would be the creation of advisory committees to control wages between men and women who work in similar jobs. Participation quotas and wage quotas for women could also be created, promoting differential treatment for those receiving such discriminatory market treatment. However, these actions have some problems of operationalization due to the difficulty of knowing the real productivity of the workers and the realization of the same or similar works, besides being socially questionable, to combat discrimination with another form of discrimination. Nevertheless, such actions could have some effect on the labor market.

As already pointed out, the creation of effective policies will only be possible by creating channels of dialogue with the different social actors and by empowering managers, government, organizations and civil servants, in order to develop concrete actions, as well as Women's and black organizations, so that they know how to pass their ideas in a clear way for policy formation (ABRAMO, 2004). In addition, there is a need to raise awareness among employers, contractors and employment agents so that they are aware of all the problems that differentiated treatment based on discrimination can generate for society as a whole, harming the insertion of women, contributing to Maintain the vicious cycle of poverty, and discourage women in the labor market.

As pointed out by Tatei (2011, p.63), one of the recommendations to try to reduce the problem of wage inequalities, especially discrimination against women, would be "to increase awareness efforts in order to intervene within the framework of traditional social values, such as the prejudice of employers with regard to the opportunities of professional specialization and access to the positions of higher hierarchical degree".

Bohnenberger (2005) points out that, even though discrimination is a practice prohibited by the Brazilian Constitution, it still exists. Thus, there are laws that prohibit this practice is essential, but it is not enough, because the discrimination is inserted in the culture of the people. According to the author $(2005,62)$ "to reverse this situation, a good start is to speak openly about discrimination, democratizing the issue, recognizing its existence and trying to overcome discriminatory practices". 
Another fact that deserves to be pointed out is that women must also contribute to this change. They need to create advocacy groups, organizing and fighting for their rights, both in the public sphere and in the private sphere. The participation of these groups in the mobilization of better working conditions is very important for the implementation of public policies. In this sense, Bohnenberger $(2005$, p. 63) points out that "it is of the utmost importance for women and blacks to know their rights, to be present and active in trade union organizations and to prepare to participate in collective bargaining [...] institutional spaces for discussion of public policies".

Therefore, the reduction of wage inequalities between men and women, especially those caused by discriminatory aspects, must be thought and carried out by all economic and social actors.

\section{Final considerations}

This article aimed to present theories that can be used to explain wage inequalities and to address public policies and actions that could be elaborated to minimize this problem.

The theories that seek to explain the wage inequalities used to explain the wage differences were: compensatory differentials, human capital, segmentation and discrimination. The theory of compensatory differentials explains the extra gains for jobs that require greater risks and insalubrity. The theory of human capital seeks to explain the differences in schooling and experience for the existence of wage differences. The theory of segmentation, however, seeks to explain the existence of wage differences in the segmentation of the market, and the theory of discrimination seeks to explain the personal characteristics of workers as the reason for the existence of such differences.

Special attention was given to the problem of wage discrimination against women, a factor that is very common in Brazilian reality. It can be said that theories of compensatory differentials, human capital and segmentation provide a real explanation for the existence of wage differentials between men and women, however, discrimination is an unacceptable social factor, since it is based on purely subjective, Being the most correct way to determine the salary of a person.

This article does not intend to exhaust the discussion on the subject, since it is a complex subject, involving many determinants. New and complementary studies on the subject are suggested, and this analysis can be done for the different races, ages, marital status, etc.

\section{References}

ABRAMO, L. W. Perspectiva de gênero e raça nas políticas públicas (Nota Técnica). Mercado de Trabalho, Rio de Janeiro: IPEA, v. 25, p. 17-21, nov. 2004. Disponível em:<http://www.ipea.gov.br/portal/images/stories/PDFs/mercadodetrabalho/mt_ 25e.pdf>. Acesso em: 18 fev. 2016.

ARBACHE, J. S. Determinação e diferencial de salários no Brasil. In: FONTES, R. (Org.); ARBEX, M. A. (Org.). Desemprego e mercado de trabalho: ensaios teóricos e empíricos. Viçosa: Editora UFV, 2000, p. 125-184. 
ARBACHE, J. S.; NEGRI, J. A. Diferenciais de salários interindustriais no Brasil: evidências e implicações. Texto para Discussão, Rio de Janeiro: IPEA, n. 918, nov. 2002. Disponível em: <http://repositorio.ipea.gov.br/handle/11058/2808>. Acesso em: 03 mar. 2016.

BANDEIRA, L. Brasil: fortalecimento da secretaria especial de políticas para as mulheres para avançar na transversalização da perspectiva de gênero nas políticas públicas. In: MELO, H. P. (Org.); BANDEIRA, Lourdes (Org.). A pobreza e as políticas de gênero no Brasil. Chile, Santiago de Chile: Comissão Econômica para a América Latina e o Caribe (CEPAL), Série Mujer y Dessarrollo, Nações Unidas, n 66, jun. 2005, p. 9-42. Disponível em: <http://repositorio.cepal.org/bitstream/handle/11362/5944/S055322.pdf?sequenc e=1>. Acesso em: 29 fev. 2016.

BARROS, R. P; MENDONÇA, R. Diferenças entre discriminação racial e por gênero e o desenho de políticas anti-discriminatórias. Revista Estudos Feministas, Florianópolis, v. 4, n. 1, p. 183-193, 1996. Disponível em: <https://periodicos.ufsc.br/index.php/ref/article/viewFile/16667/15236>. Acesso em: 04 out. 2016.

BECKER, G. S. Investment in human capital: A theoretical analysis. Journal of political economy, Chicago, v. 70, n. 5, p. 9-49, Oct. 1962. Disponível em: $<$ http://www.jstor.org/stable/1829103?seq=1\#page_scan_tab_contents>. Acesso em: 18 fev. 2016.

BELTRÃO, K. I; ALVES, J. E. D. A reversão do hiato de gênero na educação brasileira no século XX. Cadernos de Pesquisa, São Paulo: Fundação Carlos Chagas, v. 39, n. 136, p. 125-156, jan./abr. 2009. Disponível em: $<$ http://publicacoes.fcc.org.br/ojs/index.php/cp/article/view/277>. Acesso em: 19 fev. 2016.

BOHNENBERGER, R. Uma análise regional da discriminação de gênero e raça no mercado de trabalho brasileiro - 1992 a 2001. Dissertação (Mestrado em Economia de Empresas), Universidade Católica de Brasília- UCB, Brasília, 2005. Disponível em: <http://www.bdtd.ucb.br/tede/tde_arquivos/2/TDE-2006-04-06T123843Z249/Publico/Trabalho\%20Final\%205.pdf>. Acesso em: 09 mar. 2016.

BRASIL. Constituição (1988). Constituição: República Federativa do Brasil. Brasília, DF: Senado Federal do Brasil, 1988. Disponível em: <http://www.planalto.gov.br/ccivil_03/Constituicao/ConstituicaoCompilado.htm>. Acesso em: 16 mai. 2016.

BRASIL. Presidência da República. Secretaria de Políticas para as Mulheres. Plano Nacional de Políticas para as Mulheres. Brasília: Secretaria de Políticas para as Mulheres, 2013. Disponível em: <http://www.compromissoeatitude.org.br/wpcontent/uploads/2012/08/SPM_PNPM_2013.pdf>. Acesso em 02 nov. 2016.

BRASIL. Ministério do Trabalho e do Emprego. RAIS- Relação Anual de Informações Sociais. Disponível em: <http://acesso.mte.gov.br/portal-mte/rais/\#2>. Acesso em: 16 mai. 2016a.

BRASIL. Ministério da Justiça e da Cidadania. Secretaria Especial de Políticas para as Mulheres. Disponível em: <http://www.spm.gov.br/sobre/a-secretaria >. Acesso em: 02 nov. 2016b.

BRASIL. Ministério da Justiça e da Cidadania. 4o Conferência Nacional de Políticas para as Mulheres. Disponível em: <http://www.spm.gov.br/4cnpm/assuntos/Documentos>. Acesso em: 02 nov. 2016c. 
BRUSCHINI, M. C. A; LOMBARDI, M. R. Instruídas e Trabalhadeiras: trabalho feminino no final do século XX. Cadernos Pagu, São Paulo, n.17-18, p. 157-196, fev. 2001. Disponível em:<http://www.scielo.br/pdf/cpa/n17-18/n17a07.pdf>. Acesso em: 23 fev. 2016.

BRUSCHINI, M. C. A; LOMBARDI, M. R. Trabalho e gênero no Brasil nos últimos dez anos. Cadernos de Pesquisa, São Paulo, v. 37, n. 132, p. 537-572, set./dez. 2007. Disponível em:<http://www.scielo.br/pdf/cp/v37n132/a0337132.pdf>. Acesso em: 23 fev. 2016.

BRUSCHINI, M. C. A; RICOLDI, A. M; MERCADO, C. M. Trabalho e gênero no Brasil até 2005: uma comparação regional. In: COSTA, A. O. et al (Org.). Mercado de trabalho e gênero: comparações internacionais. Rio de Janeiro: Editora FGV, 2008, p.15-33.

CHAHAD, J. P. Z. Flexibilidade no mercado de trabalho, proteção aos trabalhadores e treinamento vocacional de força de trabalho: a experiência de América Latina e perspectivas (análise do caso brasileiro). Santiago de Chile: Comissão Econômica para a América Latina e o Caribe (CEPAL), Documentos de Proyectos, Nações Unidas, n. 246, mar. 2009. Disponível em: <http://repositorio.cepal.org/handle/11362/3657>. Acesso em: 18 fev. 2016.

CIRINO, J. F. Participação feminina e rendimento no mercado de trabalho: análise da decomposição para o Brasil e as regiões metropolitanas de Belo Horizonte e Salvador. Tese (Doutorado Doctor Scientiae em Economia Aplicada), Universidade Federal de Viçosa, Viçosa, 2008. Disponível em: <http://www.locus.ufv.br/handle/123456789/111>. Acesso em: 09 mar. 2016.

FERNANDES, R. Desigualdade salarial: aspectos teóricos. Rio de Janeiro: Ipea, p.150, out. 2002. Disponível em: <https://www.en.ipea.gov.br/agencia/images/stories/PDFs/livros/capitulo1_desigu aldade.pdf>Acesso em: 03 mar. 2016.

FERREIRA, V. A globalização das políticas de igualdade entre os sexos: do reformismo social ao reformismo estatal. In: GODINHO, T. (Org.); SILVEIRA, M. L. (Org.). Políticas públicas e igualdade de gêneros. São Paulo: Prefeitura do Município de São Paulo, Coordenadoria Especial da Mulher, n. 8, 2004, p. 77-102. Disponível em: <http://library.fes.de/pdf-files/bueros/brasilien/05630.pdf >. Acesso em: 01 mar. 2016.

FIUZA-MOURA, F. K. Diferenciais de salários na indústria brasileira por sexo, cor e intensidade tecnológica. 100 f. Dissertação (Mestrado em Economia Regional) Universidade Estadual de Londrina - UEL, Centro de Estudos Sociais Aplicados, Londrina, $2015 . \quad$ Disponível em: <http://www.uel.br/pos/economia/arq/DISSERTACOES/Flavio\%20Kaue\%20\%20Dissertacao.pdf>. Acesso em: 15 fev. 2016.

GODINHO, T. Construir a igualdade combatendo a discriminação. In: GODINHO, T. (Org.); SILVEIRA, M. L. (Org.). Políticas públicas e igualdade de gêneros. São Paulo: Prefeitura do Município de São Paulo, Coordenadoria Especial da Mulher, n. 8, 2004, p. 55-64. Disponível em: <http://library.fes.de/pdf-files/bueros/brasilien/05630.pdf >. Acesso em: 01 mar. 2016.

LEONE, E. T; BALTAR, P. Diferenças de rendimento do trabalho de homens e mulheres com educação superior nas metrópoles. Revista Brasileira de Estudos de População, São Paulo, v. 23, n. 2, p. 355-367, jul./dez. 2006. Disponível em: <http://www.scielo.br/pdf/rbepop/v23n2/a10v23n2>. Acesso em: 26 fev. 2016.

LIMA, R. Mercado de trabalho: o capital humano e a teoria da segmentação. Revista Pesquisa e Planejamento Econômico, Rio de Janeiro, v. 10, n. 1, p- 217-272, abr. 1980. 
<http://www.ppe.ipea.gov.br/index.php/ppe/article/view/497>. Acesso em: $11 \mathrm{de}$ mar. 2016.

LOUREIRO, P. R. A. Uma resenha teórica e empírica sobre economia da discriminação. Revista Brasileira de Economia, Rio de Janeiro, v. 57, n. 1, p. 125-157, jan./mar. 2003. Disponível em: <http://www.scielo.br/pdf/rbe/v57n1/a05v57n1.pdf>. Acesso em: 22 fev. 2016.

MELO, H. P. Gênero e pobreza no Brasil. In: MELO, H. P. (Org.); BANDEIRA, L. (Org.). A pobreza e as políticas de gênero no Brasil. Chile, Santiago de Chile: Comissão Econômica para a América Latina e o Caribe (CEPAL), série Mujer y Dessarrollo, Nações Unidas, $\mathrm{n}$ 66, jun. 2005, p. 9-42. Disponível em: <http://repositorio.cepal.org/bitstream/handle/11362/5944/S055322.pdf?sequenc e=1>. Acesso em: 23 fev. 2016.

RAMOS, L; VIEIRA, M. L. Desigualdade de rendimentos no Brasil nas décadas de 80 e 90: evolução e principais determinantes. Texto para Discussão, Rio de Janeiro: IPEA, n. 803, jun. 2001. Disponível em: <http://repositorio.ipea.gov.br/handle/11058/1979>. Acesso em 26 fev. 2016.

ROCHA, R. C. B.; PERO, V. Discriminação racial e educação no Brasil. Sinais Sociais, Rio de Janeiro, v. 1, n. 33, p. 122-155, abr. 2007. Disponível em: <http://www.sesc.com.br/portal/publicacoes/sesc/revistas/sinaissociais/n3/n3>. Acesso em: 19 fev. 2016.

SABINO, M. J. C; LIMA, P. V. P. S. Igualdade de gênero no exercício do poder. Revista Estudos Feministas, Florianópolis, v. 23, n. 3, set./dez. 2015. Disponível em:<https://periodicos.ufsc.br/index.php/ref/article/viewFile/41762/30376>.

Acesso em: 02 mar. 2016.

SATEL, C. I. R. Desigualdade de rendimentos do trabalho no Paraná no período 2002 a 2009: uma análise quantifica para o quartil $0,25^{\circ}$ e percentil $0,90^{\circ}$ da distribuição de rendimentos. 118 f. Dissertação (Mestrado em Economia Regional) Universidade Estadual de Londrina- UEL, Centro de Estudos Sociais Aplicados, Londrina, 2011. Disponível em: <http://www.bibliotecadigital.uel.br/document/?code=vtls000169818>. Acesso em: 08 mar. 2016.

SCHULTZ, T. W. Investment in human capital. The American Economic Review, Pittsburgh, v. 51, n. 1, p. 1-17, Mar. 1961. Disponível em: < http://www.jstor.org/stable/1818907>. Acesso em 18 fev. 2016.

SILVEIRA, M. L. Políticas públicas de gênero: impasses e desafios para fortalecer a agenda política na perspectiva da igualdade. In: GODINHO, T. (Org.); SILVEIRA, M. L. (Org.). Políticas públicas e igualdade de gêneros. São Paulo: Prefeitura do Município de São Paulo, Coordenadoria Especial da Mulher, n. 8, 2004, p. 65-75. Disponível em: <http://library.fes.de/pdf-files/bueros/brasilien/05630.pdf >. Acesso em: 01 mar. 2016.

SOARES, V. Políticas públicas para igualdade: papel do Estado e diretrizes. In: GODINHO, T. (Org.); SILVEIRA, M. L. (Org.). Políticas públicas e igualdade de gêneros. São Paulo: Prefeitura do Município de São Paulo, Coordenadoria Especial da Mulher, n. 8, 2004, p. 113-126. Disponível em: <http://library.fes.de/pdffiles/bueros/brasilien/05630.pdf >. Acesso em: 01 mar. 2016.

TATEI, F. Desigualdades no mercado de trabalho da América Latina: a discriminação por sexo entre os trabalhadores com ensino superior no Brasil e no México. Dissertação (Mestrado em Integração da América Latina), Universidade de São PauloUSP, Escola de Artes, Ciências e Humanidades, São Paulo, 2011. Disponível em: <http://www.teses.usp.br/teses/disponiveis/84/84131/tde-18122012-

105148/en.php>. Acesso em: 16 mai. 2016. 
YANNOULAS, S. C. Dossiê: Políticas públicas e relações de gênero no mercado de trabalho. Brasília: CFEMEA - Centro Feminista de Estudos e Assessoria, nov. 2002. Disponível

em: <https://www.nescon.medicina.ufmg.br/biblioteca/imagem/2043.pdf>. Acesso em: 19 fev. 2016.

Received: 04/26/2017

Approved: 05/09/2017 